\title{
Sex differences in the risk of vascular disease associated with diabetes
}

\author{
Rianneke de Ritter ${ }^{1,2 \dagger}$, Marit de Jong ${ }^{3 \dagger}$, Rimke C. $\operatorname{Vos}^{3,4}$, Carla J. H. van der Kallen ${ }^{1,2}$, Simone J. S. Sep ${ }^{1,2}$, \\ Mark Woodward ${ }^{5,6,7}$, Coen D. A. Stehouwer ${ }^{1,2}$, Michiel L. Bots ${ }^{3}$ and Sanne A. E. Peters ${ }^{3,5^{*}}$
}

\begin{abstract}
Diabetes is a strong risk factor for vascular disease. There is compelling evidence that the relative risk of vascular disease associated with diabetes is substantially higher in women than men. The mechanisms that explain the sex difference have not been identified. However, this excess risk could be due to certain underlying biological differences between women and men. In addition to other cardiometabolic pathways, sex differences in body anthropometry and patterns of storage of adipose tissue may be of particular importance in explaining the sex differences in the relative risk of diabetes-associated vascular diseases. Besides biological factors, differences in the uptake and provision of health care could also play a role in women's greater excess risk of diabetic vascular complications. In this review, we will discuss the current knowledge regarding sex differences in both biological factors, with a specific focus on sex differences adipose tissue, and in health care provided for the prevention, management, and treatment of diabetes and its vascular complications. While progress has been made towards understanding the underlying mechanisms of women's higher relative risk of diabetic vascular complications, many uncertainties remain. Future research to understanding these mechanisms could contribute to more awareness of the sex-specific risk factors and could eventually lead to more personalized diabetes care. This will ensure that women are not affected by diabetes to a greater extent and will help to diminish the burden in both women and men.
\end{abstract}

\section{Background}

Diabetes is one of the most common chronic diseases globally. In 2017, an estimated 425 million adults, $8.4 \%$ of women and $9.1 \%$ of men, had diabetes, and an additional 352 million adults were at risk of developing the condition [1]. The prevalence of diabetes is expected to further rise by $48 \%$, to 629 million affected adults aged between 20 and 79 years by 2045 [1]. The two main types of diabetes are diabetes type 1 and diabetes type 2 , accounting for $\sim 5-10 \%$ and $\sim 90 \%$ of all individuals with diabetes, respectively $[1,2]$. Although diabetes type 2 is most often diagnosed at middle or old age, it is increasingly common in children, adolescents, and young adults, often as a consequence of obesity, physical inactivity, and poor dietary habits $[1,3]$.

\footnotetext{
* Correspondence: sanne.peters@georgeinstitute.ox.ac.uk

Rianneke de Ritter and Marit de Jong shared first authorship.

${ }^{+}$Rianneke de Ritter and Marit de Jong contributed equally to this work.

${ }^{3}$ Julius Center for Health Sciences and Primary Care, University Medical

Center Utrecht, Utrecht University, Utrecht, The Netherlands

${ }^{5}$ The George Institute for Global Health, University of Oxford, Oxford, UK Full list of author information is available at the end of the article
}

Diabetes is a major contributor to premature mortality. In 2017, an estimated 4 million deaths of people aged between 20 and 79 years were attributed to diabetes [1], making it the seventh most common cause of death worldwide [4]. More women than men die of diabetes on a global scale: 2.1 versus 1.8 million in 2017 [1]. The only regions where more men than women die from diabetes are North America and the Caribbean region [1]. Individuals with diabetes are at increased risk of cardiovascular complications, chronic kidney disease, certain cancers, physical and cognitive impairment (i.e., dementia), depression, and respiratory and other infectious diseases $[1,5,6]$.

Cardiovascular disease is the most common complication of diabetes and can be broadly categorized in microvascular complications (classically, neuropathy, nephropathy, and retinopathy) and macrovascular complications including coronary artery disease, stroke, and peripheral arterial disease. Individuals with diabetes are two to three times more likely to develop cardiovascular disease compared to individuals without diabetes [1].

(c) The Author(s). 2020 Open Access This article is distributed under the terms of the Creative Commons Attribution 4.0 International License (http://creativecommons.org/licenses/by/4.0/), which permits unrestricted use, distribution, and reproduction in any medium, provided you give appropriate credit to the original author(s) and the source, provide a link to the Creative Commons license, and indicate if changes were made. The Creative Commons Public Domain Dedication waiver (http://creativecommons.org/publicdomain/zero/1.0/) applies to the data made available in this article, unless otherwise stated. 
However, not everyone with diabetes has the same excess risk of cardiovascular disease. Large-scale systematic reviews with meta-analyses have demonstrated that the excess risk of macrovascular complications associated with diabetes is substantially greater in women than men $[7,8]$. The relative risks of incident coronary heart disease (CHD) and stroke, respectively, associated with diabetes have been estimated to be $44 \%$ and $27 \%$ higher in women than men $[7,8]$. Likewise, another meta-analysis of 68 prospective studies has shown that, after adjustment for major vascular risk factors, diabetes was associated with a nearly $50 \%$ higher occlusive vascular mortality rate among women than men [9]. The excess risk of vascular mortality among women conferred by diabetes was especially high among those between the age of 35 and 59 years, with almost a six times higher occlusive vascular death rate among women and a nearly two and a half times higher rate among men [9]. Another meta-analysis demonstrated that diabetes was associated with a 19\% higher relative risk of vascular dementia in women than men [10]. A sex differential in the consequences of diabetes has also been shown for end stage renal disease, where the relative risk of end-stage renal disease was $38 \%$ higher among women than men [11]. Since $90 \%$ of individuals with diabetes have type 2 diabetes, most individuals with diabetes who were included in these metaanalyses had type 2 diabetes. Nevertheless, a meta-analysis that specifically focused on type 1 diabetes has shown that women with type 1 diabetes had almost a 40\% higher relative risk of all-cause mortality, and a $200 \%$ higher relative risk of fatal and nonfatal vascular events, compared with men with type 1 diabetes [12].

In addition to vascular disease, sex differences may also exist in the association between diabetes and nonvascular diseases. A recent meta-analysis has shown that women have a $6 \%$ greater relative risk of diabetesassociated cancer, with some variation by cancer type [13]. Sex differences in other non-vascular diseases require further study. Figure 1 summarizes the results from the abovementioned meta-analyses.

While the greater excess risk of vascular complications conferred by diabetes in women compared with men has been well described, mechanisms underpinning the sex difference have not been identified in full. In this review, we will first discuss sex differences in biological factors, with a specific focus on adipose tissue, and secondly, we will discuss sex differences in the uptake and provision of health care. These mechanisms may be involved in explaining the sex difference in the vascular consequences of diabetes. Although some aspects may differ by type of diabetes, we shall mainly focus on diabetes in general, while acknowledging that most cases with diabetes would have type 2 diabetes.

\section{Biological aspects}

Women and men are subject to similar environmental exposures during their life course, but they are biologically different. For that reason, the excess risk of diabetesassociated vascular disease in women compared with men could be due to physiological, such as hormonal or genetic, differences between women and men.

To diagnose diabetes, an arbitrary cutoff value of a continuous trait is used, such as fasting blood glucose (FG) or glycated hemoglobin (HbA1c). Nevertheless, there is compelling evidence of a progressive association between various measures of glycemia and the risk of vascular disease, both above and below the clinical threshold for diabetes. It has been postulated that, compared with men, metabolic risk factors in women has to deteriorate to a greater

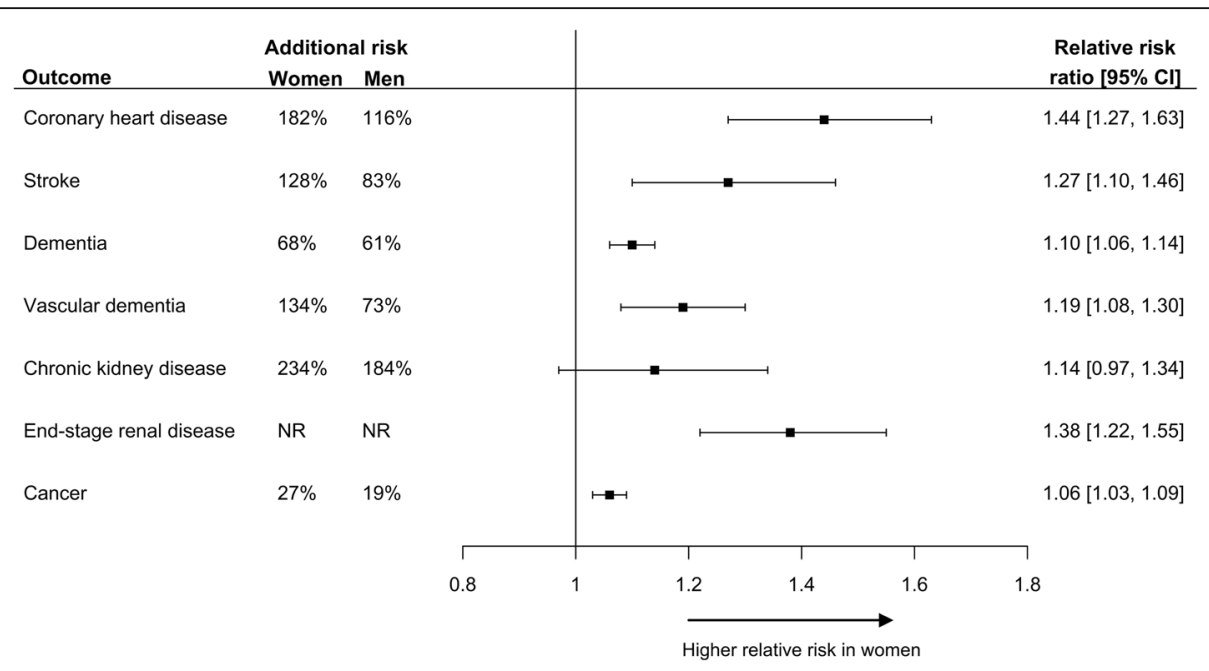

Fig. 1 Results from prior meta-analyses of sex differences in the effects of diabetes on vascular outcomes and cancer expressed as the womento-men ratio of relative risks (RRR) and the additional risks [7, 8, 10, 11, 13]. RRR, relative risk ratio; RR, relative risk; NR, not reported 
magnitude across this continuous trait for diabetes to develop $[8,14]$. As a consequence, the exposure to a hazardous cardiometabolic environment in the development of diabetes may be more pronounced in women $[8,15]$. This hypothesis is supported by a study that found that, on average, men have prediabetes for 8.5 years and women for 10.3 years prior to the development of diabetes [16]. Moreover, several studies have found a relatively greater increase in the levels of cardiovascular risk factors, in women with diabetes compared with women without diabetes, opposed to their male counterparts [17-20]. Additional to the different impact of risk factors, sex differences in vascular and hormonal pathophysiology could partially explain women's higher relative risk on diabetes-associated vascular diseases [21]. These potential explanations will be outlined in the next paragraphs.

\section{Diabetes-associated sex differences in adiposity}

Sex differences in body anthropometry and patterns of storage of adipose tissue may be of particular importance in explaining the sex differences in the diabetes-associated risk of vascular disease [22]. Among 500,000 individuals of the UK Biobank, waist circumference and body mass index (BMI) differed more between women with and without diabetes than between men with and without diabetes [23]. Moreover, when first diagnosed with diabetes, women have a BMI that is nearly $2 \mathrm{~kg} / \mathrm{m}^{2}$ higher than that of men, despite similar levels of HbA1c [24, 25]. These sex differences in anthropometric characteristics among those with and without diabetes may be linked to differential patterns of fat storage in adipose tissue in women and men [22].

Ample evidence exists to show that excess adipose tissue is causally linked to the development of type 2 diabetes and vascular disease [26, 27]. However, it is becoming increasingly apparent that adipose tissue in different parts of the body has different biochemical profiles. In contrast to (peripheral) subcutaneous fat, excess visceral fat and fat in ectopic tissues, like skeletal muscle and the liver, has specifically been associated with insulin resistance [28-30]. This interferes with insulin signaling pathways, which eventually could lead to diabetes [28-30]. Sex differences in the preferred location of fat storage could have an effect on the duration of the development of insulin resistance and diabetes and the consequent deterioration of other related cardiometabolic risk factors. This process is illustrated in Figs. 2 and 3. Women are more likely to store fat subcutaneously and on their lower extremities, whereas men are more likely to store fat in the abdominal region [31]. Correspondingly, men have a substantially higher amount of visceral and ectopic fat compared with premenopausal women, independent of BMI and the amount of total body fat $[32,33]$. The preferential deposition of excess fat in visceral and ectopic tissues in men could lead to a faster transition to insulin resistance and diabetes, whereas women may need to gain more weight and related metabolic risk factors might need to deteriorate to a greater extent than in men to reach the same levels of visceral and
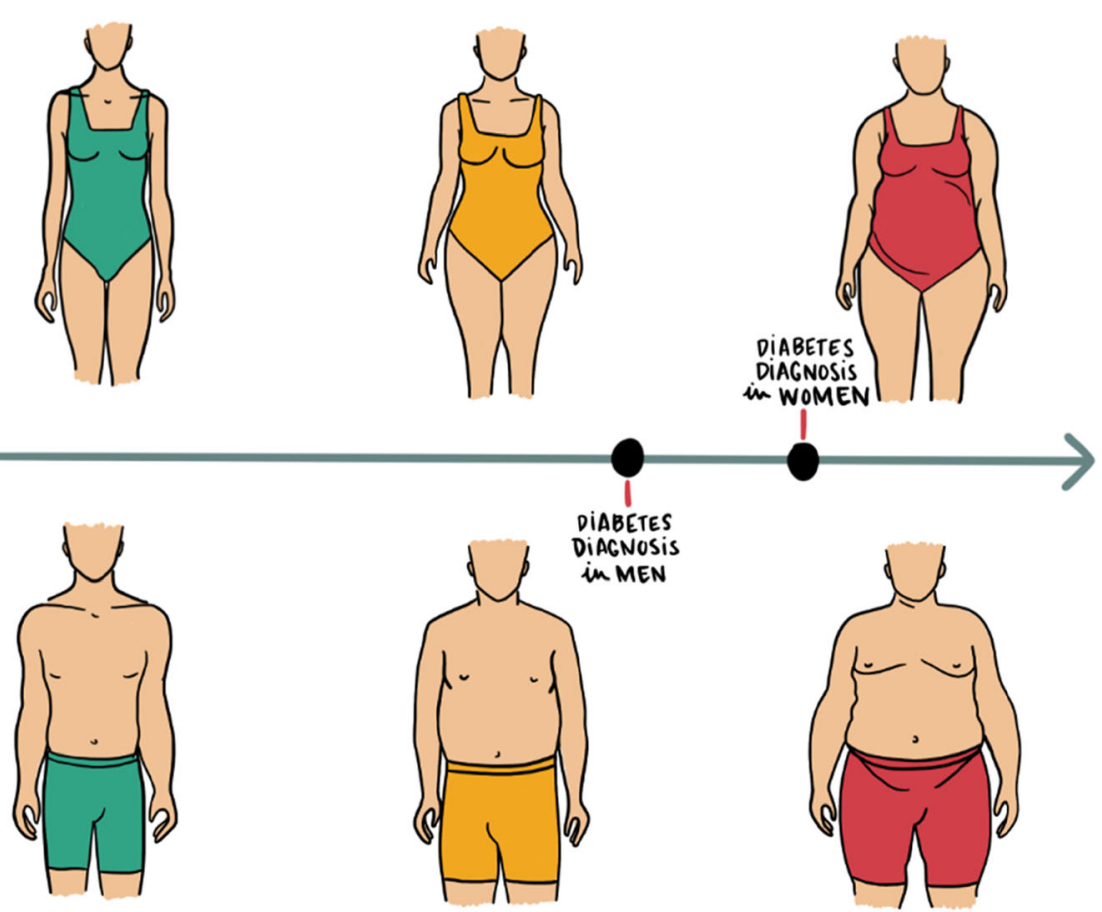

Fig. 2 Sex differences in visceral and subcutaneous fat and their association with the time of diagnosis of diabetes 


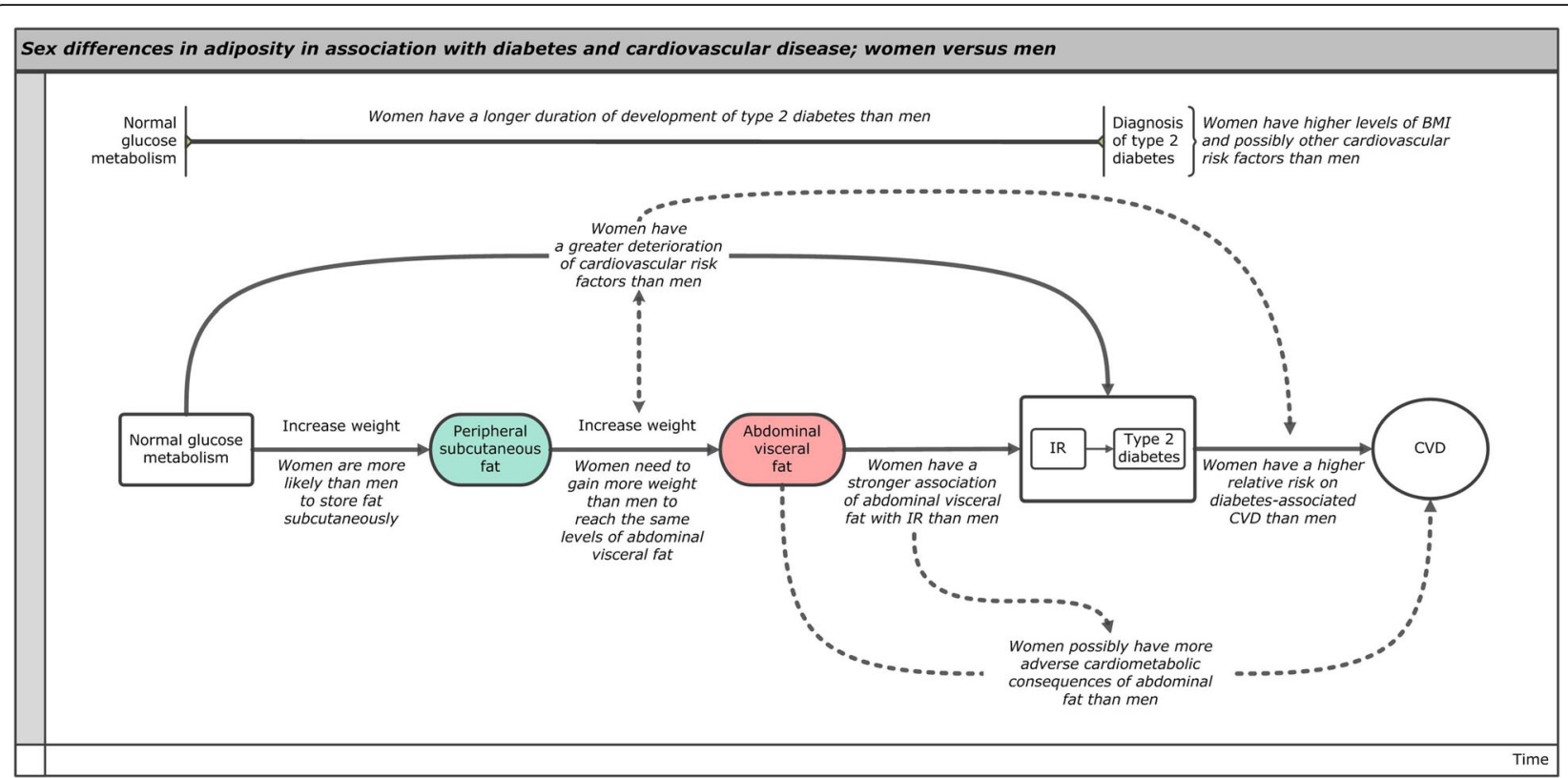

Fig. 3 Sex differences in adiposity in association with diabetes and cardiovascular disease. The figure illustrates the associations between adiposity, insulin resistance, type 2 diabetes, and cardiovascular disease in women compared with men. BMI, body mass index; IR, insulin resistance; CVD, cardiovascular disease

ectopic fat that are required to develop insulin resistance and eventually diabetes (Fig. 3) [34, 35].

Next to the different metabolic effects of adipose tissue in different parts of the body, abdominal visceral adipose tissue itself seems to have a stronger association with insulin resistance in women than in men, suggesting that excess visceral adipose tissue is more strongly linked to diabetes in women than in men [36]. Likewise, recent findings from the UK Biobank demonstrated that higher waist circumferences and waist-to-hip ratio conferred a greater excess risk of myocardial infarction in women than in men [34]. These findings suggest that excess adipose tissue in the abdominal region may have more adverse cardiometabolic consequences in women than men, which may be explained by sex difference in insulin resistance at a given amount of adipose tissue (Fig. 3).

Finally, there is compelling evidence that obesity and its associated metabolic dysfunction suppresses women's protective effect of sex-hormones on cardiovascular disease [37]. Adipocytes overfilled with lipids release leptin, which can promote activation of the sympathetic nervous system and the renin-angiotensin system and could stimulate the secretion of aldosterone [38]. In turn, aldosterone is associated with excessive mineralocorticoid receptor signaling on endothelial cells, which play a major role in obesity-associated cardiovascular disease [37, 38]. Women may be predisposed to heightened endothelial mineralocorticoid receptor activation. This might be explained by higher endogenous expression of endothelial mineralocorticoid receptors in blood vessels in women than in men, possibly driven by progesterone receptor activation in in endothelial cells [37]. Moreover, these disadvantageous obesity-associated mechanisms in women may be stronger in the presence of type 2 diabetes, since women have a higher BMI and subsequently more adipose tissue at moment of diagnosis of diabetes than men $[24,25]$.

\section{Diabetes-associated sex differences in other cardiovascular risk factors and vascular pathophysiology}

As previously mentioned, it has been hypothesized that women have to undergo greater metabolic deterioration to develop diabetes than men. This hypothesis is also supported by studies that found that sex differences in metabolic risk factors already occur in the transition from normoglycemia to elevated glucose levels and diabetes $[39,40]$. During 8 years of follow-up, women who converted to diabetes showed relatively worse levels of total cholesterol, HDL cholesterol, triglycerides, and diastolic blood pressure at baseline than men who converted to diabetes, compared with participants of the same sex who did not develop diabetes [40]. Correspondingly with the classic risk markers, progression from normal glucose metabolism to elevated levels of fasting glucose in women was associated with relatively greater endothelial dysfunction, a higher prevalence of hypertension, and a greater degree of dysregulated fibrinolysis and coagulation than in male counterparts [39]. Compared with men, women generally have higher fibrinolytic potential and a better endothelial function, but these protective effects are diminished in the presence of type 2 diabetes [21]. Additionally, the coagulation system is in a more pro-thrombotic state in diabetic women 
compared with diabetic men [21]. Finally, type 2 diabetes may induce a greater immune response and impairment of cellular defense mechanisms against oxidative stress in women than in men [41]. These sex differences in hyperglycemia-induced hemodynamics might be explained by complex interactions between insulin and estrogen signaling [42]. Whether these differences explain women's higher relative risk on diabetes-associated cardiovascular disease requires further study.

Despite the evidence above regarding traditional risk factors, results from the meta-analyses that demonstrated that sex differences exist in the relative risk of vascular disease associated with diabetes were adjusted for traditional cardiovascular risk factors. Hence, it is conceivable that sex differences in traditional risk factor levels alone cannot fully explain the higher relative risk of women in diabetes-associated vascular disease, even though there may be unmeasured confounding. Moreover, key risk factors for vascular disease, such as total cholesterol, blood pressure, and BMI, have each been found to have a continuous log-linear association with occlusive vascular mortality in diabetic and non-diabetic individuals, which does not differ by sex [9]. Nevertheless, only baseline information about cardiovascular risk factor levels in participants with or without diabetes has been taken into account in the meta-analyses, not the possibly larger deterioration in cardiovascular risk factors levels in the conversion to diabetes. It is therefore conceivable that the risk factor changes in the conversion to diabetes explain some of the higher relative risk of vascular disease in women compared to men.

\section{Future perspective}

In future studies, it would be useful to investigate possible sex differences in cardiovascular risk factor levels associated with glucose metabolism status and across levels of glycemic control. Previous results from our research group indicated that there are already sex differences in cardiometabolic risk factors to women's disadvantage before the development of type 2 diabetes, albeit weaker than in type 2 diabetes, with greater differences in systolic blood pressure and lipid levels among women than men with prediabetes and across levels of HbA1c [43]. To further understand the effects of sex differences in adiposity, detailed body composition and body fat distribution measurements conducted by DEXA and MRI can be used. These methods are appropriate to assess the extent to which fat and lean mass, visceral and subcutaneous fat, and the fat content of the liver and pancreas are differentially associated with glucose metabolism status in women and men and how such differences can explain women's greater excess vascular disease risk associated with diabetes.

\section{Health care aspects}

In addition to sex differences in biological aspects, disparities in the uptake and provision of healthcare may in part explain sex differences in diabetes-related vascular complications (Fig. 4).

\section{Diabetes management}

One of the primary goals in management of diabetes is the delay and prevention of vascular morbidity and mortality [44]. Currently, many guidelines on diabetes management exist. Most of these evidence-based guidelines provide broadly similar recommendations for both sexes on diabetes management and prevention of diabetesrelated complications and target lifestyle factors, including smoking behavior, physical activity, diet, and weight control, and adequate management of blood pressure, cholesterol, and glucose levels (Table 1) [3, 45].

\section{Differences in health care provision}

Sex differences in health care provision can broadly occur at three levels. There may be sex differences in the assessment and monitoring of vascular risk factors, in drug and lifestyle interventions for the management of risk factors, and in risk factor control among those treated. Early detection of suboptimal vascular risk factors and subsequent interventions-either lifestyle or pharmacological-significantly improves clinical outcomes [3]. Thus, any potential sex differences in the assessment or monitoring of vascular risk factors or differences in the initiation of lifestyle and/or pharmacological interventions may result in less optimal treatment, inadequate risk factor control, and consequently more severe clinical outcomes.

Two recent studies assessed sex differences in health care provision for the prevention of CHD [46, 47]. Within the general population of Australia, women were less likely to receive cardiovascular risk factor screening compared with men. However, high-risk women or women with a history of cardiovascular disease aged 65 years or older were more likely to be prescribed recommended drugs than men [46]. A large study including 10,000 individuals with coronary heart disease across Europe, Asia, and the Middle East found that risk factor management of secondary prevention was generally worse in women than men [47].

Several studies have been published on sex disparities in the management of diabetes, mainly with respect to screening of risk factors and risk factor control (Table 2). Overall, these studies have reported mixed findings regarding the presence, magnitude, and direction of sex differences in diabetes care and no definite conclusion about the impact of differences in health care provision on sex disparities in diabetes and its related cardiovascular complications can be 


\section{Potential disparities in the uptake and provision of health care; women versus men}

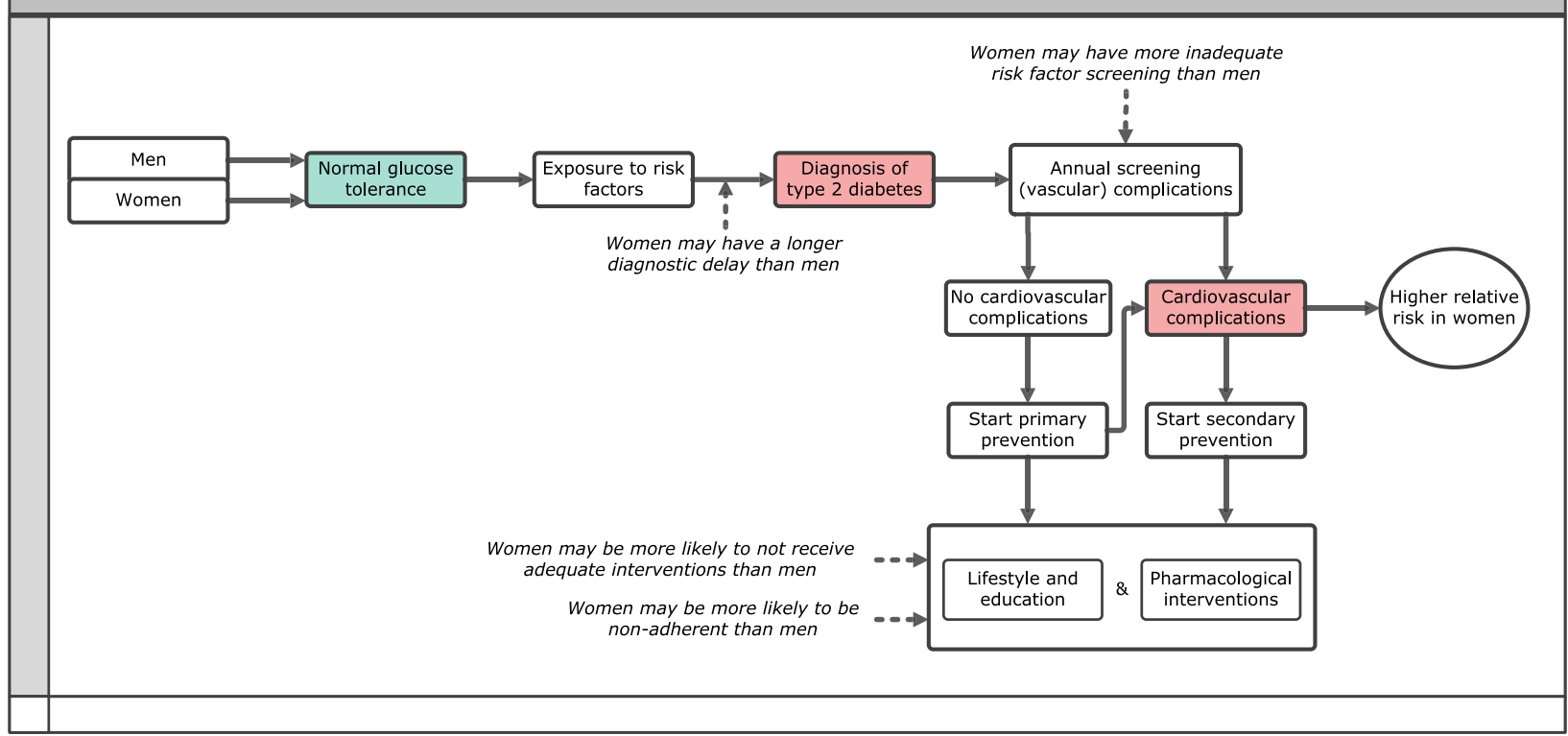

Fig. 4 Disparities in the uptake and provision of healthcare may in part explain the excess risk of vascular disease in women with diabetes compared to their male counterparts. Potential differences in the uptake and provision of healthcare between the sexes may occur throughout the pathway - starting with healthy men and women being exposed to certain risk factors, at some point being diagnosed with diabetes and eventually developing cardiovascular complications_-and may include, i.e., diagnostic delay, inadequate risk factor screening, disparities in adequate interventions, and non-adherence as shown by the arrows. The green-colored box displays normal glucose tolerance, and the redcolored boxes display negative events (i.e., type 2 diabetes, cardiovascular complications) irrespective of the sexes

Table 1 Standards of care for the management of diabetes according to the recommendations from the International Diabetes Federation

Standards of care for the management of diabetes by the International Diabetes Federation [3, 45]

\begin{tabular}{|c|c|c|}
\hline Risk factor screening & Lifestyle and education & Drug interventions and target values \\
\hline $\begin{array}{l}\text { Clinical assessment: } \\
\text { - Weight, BMI, waist circumference, } \\
\text { blood pressure, screening for } \\
\text { retinopathy (every } 1 \text { to } 2 \text { years) and } \\
\text { peripheral neuropathy, feet exam } \\
\text { (every year), screening for macrovascular } \\
\text { disease (if patient is symptomatic). } \\
\text { Biochemical assessment: } \\
\text { - HbA1c, lipid spectrum, renal function } \\
\text { (every year) } \\
\text { Lifestyle assessment: } \\
\text { - Smoking status, overweight, physical } \\
\text { activity, diet }\end{array}$ & $\begin{array}{l}\text { Education: } \\
\text { - Referral to diabetes education program } \\
\text { Diet: } \\
\text { - Reduce caloric intake with obesity or } \\
\text { overweight, if possible referral to a dietician } \\
\text { - Prefer high fiber and low-glycemic index foods } \\
\text { - Avoidance of sugar, sweets, and sweetened } \\
\text { beverages } \\
\text { Physical activity: } \\
\text { - Increase of physical activity } \\
\text { Habits: } \\
\text { - Avoid smoking } \\
\text { - Avoid excess alcohol intake }\end{array}$ & $\begin{array}{l}\text { Start lipid-lowering drugs: } \\
\text { - T2DM and established CVD } \\
\text { - T2DM, no established CVD, } \geq 40 \text { years } \\
\text { and LDL cholesterol > } 100 \mathrm{mg} / \mathrm{dL} \\
\text { - T2DM, no established CVD, LDL } \\
\text { cholesterol > } 70 \mathrm{mg} / \mathrm{dL} \text { may benefit } \\
\text { especially with high 10-year CVD risk } \\
\text { Start glucose-lowering drugs: } \\
\text { - General HbA1c target < 7\%, }>8 \% \text { is } \\
\text { generally unacceptable } \\
\text { - HbA1c levels between } 7.5 \text { and } 8 \% \\
\text { may be acceptable for patients using } \\
\text { multiple drugs, if expected survival is } \\
\text { limited, cognitive impairment CKD or } \\
\text { severe CVD associated with multiple } \\
\text { comorbidities. } \\
\text { Start antihypertensive drugs: } \\
\text { - Diastolic target } 80 \text { mmHg } \\
\text { - Systolic target of } 130 \text { to } 140 \text { mmHg } \\
\text { Start ACE-inhibitor or ARB: } \\
\text { - Persistent albuminuria }\end{array}$ \\
\hline
\end{tabular}


Table 2 Results from studies reporting on sex differences in screening, risk factor control, and drug interventions for diabetes

\begin{tabular}{|c|c|c|c|}
\hline & Women do better & Women do worse & No difference between sexes \\
\hline \multicolumn{4}{|l|}{ Screening (vascular) complications } \\
\hline Doctor visit & 62 & & \\
\hline BMI & & 44 & 63,79 \\
\hline (Systolic) blood pressure & 44,62 & 59 & $52,61,63$ \\
\hline Retinopathy & $54,55,58,62,80$ & $52,57,81,82$ & 79,83 \\
\hline Feet exam & & $44,52,83$ & 57,62 \\
\hline $\mathrm{HbA1c}$ & 58,80 & $55^{11}, 56,61^{* *}$ & $\begin{array}{l}44,52,53,54,55^{\ddagger}, 57,59,61^{\sim}, 62,63,79,81 \\
82,83\end{array}$ \\
\hline Lipid profile/total cholesterol/LDL cholesterol & & $44,52,53,55^{\natural}, 56,59,61^{* *}, 81,84$ & $54,57,55^{\ddagger}, 58,61^{\sim}, 63,79,80,82,83$ \\
\hline Nephropathy & & 52,55 & 58,79 \\
\hline Urine albumin & & $44,81,82$ & 53,57 \\
\hline Serum creatinine & 44 & $61^{* *}, 81$ & $61^{\sim}$ \\
\hline Smoking status & 59 & 44,79 & \\
\hline Screened for diabetes complications & 63,80 & $44,59,85$ & $80,82,83$ \\
\hline \multicolumn{4}{|l|}{ Risk factor control } \\
\hline \multicolumn{4}{|l|}{ Being on target for } \\
\hline $\mathrm{HbA1c}$ & 53,57 & $50^{*}, 51^{*}, 52,79,86$ & $49,50,51^{\dagger}, 54,55,56,58,59,60,61$ \\
\hline (Systolic) blood pressure & $50^{+}$ & $49^{*}, 50^{*}, 51^{*}, 52$ & $49^{\dagger}, 51^{\dagger}, 57,59,60,61,79$ \\
\hline Total cholesterol/LDL cholesterol & & $48,49^{*}, 50,51,52,53,54,55,56,57,58,59$ & $49^{\dagger}, 60,61,79$ \\
\hline BMl & & 50,52 & \\
\hline Smoking status (non-smoker) & 50 & & 59 \\
\hline \multicolumn{4}{|l|}{ Being off target despite drug prescription } \\
\hline Glucose-lowering drugs & & 52 & \\
\hline Lipid-lowering drugs & & 52 & \\
\hline Antihypertensive drugs & & & 52 \\
\hline \multicolumn{4}{|l|}{ Receiving drug prescription and being on target } \\
\hline Glucose-lowering drugs & & 87 & 63 \\
\hline Lipid-lowering drugs & & 63,87 & \\
\hline Antihypertensive drugs & 63 & $87^{*}$ & $87^{\dagger}$ \\
\hline \multicolumn{4}{|l|}{ Drug interventions } \\
\hline \multicolumn{4}{|l|}{ Being off target and no prescription } \\
\hline Glucose-lowering drugs & 52 & & \\
\hline Lipid-lowering drugs & & & 52 \\
\hline Antihypertensive drugs & 52 & & \\
\hline ACE-I or ARB & & 52 & \\
\hline \multicolumn{4}{|l|}{ Being off target and prescription } \\
\hline Glucose-lowering drugs & & & $49,51,63$ \\
\hline Lipid-lowering drugs & & $51^{*}, 53$ & $49,51^{\dagger}, 63$ \\
\hline Antihypertensive drugs & & & $49,51,63$ \\
\hline ACE-I or ARB & & & 53 \\
\hline
\end{tabular}

drawn. According to most studies, women are less likely to attain risk factor control for LDL cholesterol compared with men [48-58], while risk factor control for $\mathrm{HbA1c}$ is more often found to be similar between sexes [49-51, 54-56, 58-61].
The National Diabetes Audit - 2012-2013 studied essential care processes and achievement of treatment targets in 2 million individuals with diabetes living in England or Wales [44]. Multivariable analyses showed that women were less likely to receive assessment of all 
eight care processes than men and that the three recommended target levels were met by $33 \%$ and $30 \%$ of men and women, respectively. Moreover, women were less likely to receive risk factor assessment of smoking status, BMI, foot surveillance, cholesterol levels, and urine albumin and more likely to receive testing of serum creatinine and blood pressure [44]. A large population-based study from Italy, including 415,294 individuals with type 2 diabetes, demonstrated that women were less likely to receive recommended care than men [52]. In particular, women were less likely to receive assessment of kidney function and foot and eye surveillance and to achieve risk factor control of HbA1c and LDL cholesterol despite drug intervention and were more likely to have a $\mathrm{BMI} \geq 30$ than men. Women were more likely to receive insulin or antihypertensive medication than men when being off target for HbA1c or blood pressure respectively, while women were less likely to receive adequate treatment despite micro/macroalbuminuria compared to men [52]. In contrast, a large cross-sectional study among 18,000 men and women with diabetes in the US from the Medical Expenditure Panel Survey Household Component showed that, over a study period of nine years, women were more likely to receive recommended care than men [62]. In adjusted analyses, women were more likely to receive annual tests for dilated eye exams and blood pressure control and to visit a doctor; no differences were found for HbAlc testing and foot surveillance than men [62].

Although studies are inconclusive about sex differences in diabetes management, implementation of diabetes management can be improved on multiple aspects for both sexes, including assessment of risk factors and risk factor control. Rossi et al. reported that women were more likely to be off target for $\mathrm{HbA1c}$ and LDL cholesterol than men, despite receiving drug interventions [52]. Similar results were found in a Dutch primary care population with diabetes, showing that women receiving lipid-lowering drugs were less likely to be on target for LDL-c and more likely to attain treatment targets for blood pressure when prescribed antihypertensive drugs than men [63]. Hence, these differences in risk factor control may be caused by differences in drug type, dosage, or adherence, which is not assessed in most studies and should be investigated further.

\section{Differences in drug adherence}

Non-adherence to drugs is a frequent, complex, and multidimensional problem, and the World Health Organization (WHO) has described non-adherence as being "the primary reason for suboptimal benefit of therapy." [64] Inadequate drug adherence results in suboptimal risk factor control and has been associated with adverse cardiovascular outcomes, including premature mortality [65-69]. Nonetheless, non-adherence remains difficult to define and absence of uniform research methods makes it challenging to study and reduce nonadherence [68].

Despite the major impact of non-adherence on cardiovascular outcomes, determinants including sex that drive non-adherence have not been fully identified. A large meta-analysis including 53 studies from diverse populations showed that only about $50 \%$ of men and $47 \%$ of women were adherent to statins and that women were an additional $10 \%$ more likely to be non-adherent than men [70]. Several meta-analyses and systematic reviews on non-adherence have shown that adherence rates in individuals with diabetes are also suboptimal [71-73]. Moreover, individuals with diabetes non-adherent to cardiovascular drugs were reported to have higher rates of all-cause mortality and higher hospital admission rates compared with adherent individuals [69]. Only a limited amount of studies have studied sex differences in non-adherence among individuals with diabetes, and these showed inconclusive results [74-78].

To further improve healthcare and to prevent and delay vascular complications, it is of major importance to identify sex-specific determinants that may contribute to non-adherence. Most studies on non-adherence rely on pharmacy claims refill data, self-report, pill count, or medication event monitoring systems. The disadvantage of these strategies is that none of these methods measure true medication intake. There is a need for studies that objectively measure medication adherence, which can be done by quantifying, through mass spectrometry, the presence of drug compounds in body fluids. By objectively studying non-adherence, more awareness about this complex and multidimensional problem can be generated and this may help health care providers to address this complex problem more easily.

\section{Perspectives and significance}

Sex differences in both biological factors as in the uptake and provision of health care could contribute to women's higher relative risk of diabetic vascular complications. While progress has been made towards understanding the underlying mechanisms, many uncertainties remain. Further research is recommended to study the impact of sex differences in biological factors and health care provision. To that end, it is important to include adequate numbers of women and men, in future studies, including in clinical trials. This could contribute to more awareness of the sex-specific risk factors of diabetic vascular complications and could eventually lead to more personalized care, including sex-specific recommendations in clinical guidelines. This will ensure that women are not affected by diabetes to a greater extent than men and will help to diminish the burden in both sexes. 


\section{Authors' contributions}

$\mathrm{MdJ}$ and RdR prepared the first draft of this review, under supervision of SP. All authors reviewed the draft paper and provided critical intellectual content. All authors gave final approval of the version to be submitted.

\section{Funding}

SAEP is supported by a UK Medical Research Council Skills Development Fellowship (MR/P014550/1). MW is supported by an Australian National Health and Medical Research Council fellowship and program grants.

\section{Availability of data and materials}

Not applicable

\section{Ethics approval and consent to participate}

Not applicable

\section{Consent for publication}

Not applicable

\section{Competing interests}

The authors declare that they have no competing interests.

\section{Author details}

'Department of Internal Medicine, Maastricht University Medical Centre+, Maastricht, The Netherlands. ${ }^{2}$ CARIM Cardiovascular Research Institute Maastricht, Maastricht University, Maastricht, The Netherlands. ${ }^{3}$ Julius Center for Health Sciences and Primary Care, University Medical Center Utrecht, Utrecht University, Utrecht, The Netherlands. ${ }^{4}$ Department Public Health and Primary Care / LUMC-Campus The Hague, Leiden University Medical Center, The Hague, The Netherlands. ${ }^{5}$ The George Institute for Global Health, University of Oxford, Oxford, UK. ${ }^{6}$ The George Institute for Global Health, University of New South Wales, Sydney, Australia. ${ }^{7}$ Department of Epidemiology, Johns Hopkins University, Baltimore, Maryland, USA.

\section{Received: 1 August 2019 Accepted: 5 December 2019}

\section{Published online: 03 January 2020}

\section{References}

1. IDF diabetes atlas - 2017 Atlas. http://www.diabetesatlas.org/resources/2017atlas.html. Accessed 6 Nov 2018.

2. American Diabetes Association. Diagnosis and classification of diabetes mellitus. Diabetes Care. 2014;37(Supplement_1):S81-90. https://doi.org/10. 2337/dc14-S081.

3. International Diabetes Federation. Global Diabetes Plan 2011-2021. 2011.

4. The top 10 causes of death. http://www.who.int/news-room/fact-sheets/ detail/the-top-10-causes-of-death. Accessed 5 Nov 2018.

5. Rao Kondapally Seshasai S, Kaptoge S, Thompson A, et al. Diabetes mellitus, fasting glucose, and risk of cause-specific death. N Engl J Med. 2011;364(9): 829-41. https://doi.org/10.1056/NEJMoa1008862.

6. Woodward M, Zhang X, Barzi F, et al. The effects of diabetes on the risks of major cardiovascular diseases and death in the Asia-Pacific region. Diabetes Care. 2003;26(2):360-6 http://www.ncbi.nlm.nih.gov/pubmed/12547863. Accessed 6 Nov 2018.

7. Peters SAE, Huxley RR, Woodward M. Diabetes as a risk factor for stroke in women compared with men: a systematic review and meta-analysis of 64 cohorts, including 775385 individuals and 12539 strokes. Lancet. 2014; 383(9933):1973-80. https://doi.org/10.1016/50140-6736(14)60040-4.

8. Peters SAE, Huxley RR, Woodward M. Diabetes as risk factor for incident coronary heart disease in women compared with men: a systematic review and meta-analysis of 64 cohorts including 858,507 individuals and 28,203 coronary events. Diabetologia. 2014;57(8):1542-51. https://doi.org/10.1007/ s00125-014-3260-6.

9. Prospective Studies Collaboration and Asia Pacific Cohort Studies Collaboration L, Herrington W, Halsey J, et al. Sex-specific relevance of diabetes to occlusive vascular and other mortality: a collaborative metaanalysis of individual data from 980793 adults from 68 prospective studies. Lancet Diabetes Endocrinol. 2018;6(7):538-46. https://doi.org/10.1016/S22138587(18)30079-2

10. Chatterjee S, Peters SAE, Woodward M, et al. Type 2 diabetes as a risk factor for dementia in women compared with men: a pooled analysis of 2.3 million people comprising more than 100,000 cases of dementia. Diabetes Care. 2016;39(2):300-7. https://doi.org/10.2337/dc15-1588.

11. Shen Y, Cai R, Sun J, et al. Diabetes mellitus as a risk factor for incident chronic kidney disease and end-stage renal disease in women compared with men: a systematic review and meta-analysis. Endocrine. 2017;55(1):6676. https://doi.org/10.1007/s12020-016-1014-6.

12. Huxley RR, Peters SAE, Mishra GD, Woodward M. Risk of all-cause mortality and vascular events in women versus men with type 1 diabetes: a systematic review and meta-analysis. Lancet Diabetes Endocrinol. 2015;3(3): 198-206. https://doi.org/10.1016/S2213-8587(14)70248-7.

13. Ohkuma T, Peters SAE, Woodward M. Sex differences in the association between diabetes and cancer: a systematic review and meta-analysis of 121 cohorts including 20 million individuals and one million events. Diabetologia. 2018;61(10):2140-54. https://doi.org/10.1007/s00125-018-4664-5.

14. Recarti C, Sep SJS, Stehouwer CDA, Unger T. Excess cardiovascular risk in diabetic women: a case for intensive treatment. Curr Hypertens Rep. 2015; 17(6):45. https://doi.org/10.1007/s11906-015-0554-0.

15. Woodward M, Peters SA, Huxley RR. Diabetes and the female disadvantage. Women's Heal. 2015;11(6):833-9. https://doi.org/10.2217/whe.15.67.

16. Bertram MY, Vos T. Quantifying the duration of pre-diabetes. Aust N Z J Public Health. 2010;34(3):311-4. https:/doi.org/10.1111/j.1753-6405.2010.00532.x.

17. Juutilainen A, Kortelainen $S$, Lehto $S$, Rönnemaa T, Pyörälä K, Laakso M. Gender difference in the impact of type 2 diabetes on coronary heart disease risk. Diabetes Care. 2004;27(12):2898-904 http://www.ncbi.nlm.nih. gov/pubmed/15562204. Accessed 7 May 2019.

18. Peters SAE, Huxley RR, Sattar N, Woodward M. Sex differences in the excess risk of cardiovascular diseases associated with type 2 diabetes: potential explanations and clinical implications. Curr Cardiovasc Risk Rep. 2015;9(7):36. https://doi.org/10.1007/s12170-015-0462-5.

19. Peters SAE, Huxley RR, Woodward M. Sex differences in body anthropometry and composition in individuals with and without diabetes in the UK Biobank. BMJ Open. 2016;6(1):e010007. https://doi.org/10.1136/ bmjopen-2015-010007.

20. Wannamethee SG, Papacosta O, Lawlor DA, et al. Do women exhibit greater differences in established and novel risk factors between diabetes and nondiabetes than men? The British Regional Heart Study and British Women's Heart Health Study. Diabetologia. 2012;55(1):80-7. https://doi.org/10.1007/ s00125-011-2284-4.

21. Arnetz L, Ekberg NR, Alvarsson M. Sex differences in type 2 diabetes: focus on disease course and outcomes. Diabetes Metab Syndr Obes. 2014;7:40920. https://doi.org/10.2147/DMSO.S51301.

22. Sattar N. Gender aspects in type 2 diabetes mellitus and cardiometabolic risk. Best Pract Res Clin Endocrinol Metab. 2013;27(4):501-7. https://doi.org/ 10.1016/j.beem.2013.05.006.

23. Peters SAE, Singhateh Y, Mackay D, Huxley RR, Woodward M. Total cholesterol as a risk factor for coronary heart disease and stroke in women compared with men: a systematic review and meta-analysis. Atherosclerosis. 2016;248:123-31. https://doi.org/10.1016/j.atherosclerosis.2016.03.016.

24. Logue J, Walker JJ, Colhoun HM, et al. Do men develop type 2 diabetes at lower body mass indices than women? Diabetologia. 2011;54(12):3003-6. https://doi.org/10.1007/s00125-011-2313-3.

25. Paul S, Thomas G, Majeed A, Khunti K, Klein K. Women develop type 2 diabetes at a higher body mass index than men. Diabetologia. 2012;55(5): 1556-7. https://doi.org/10.1007/s00125-012-2496-2.

26. Laviola L, Perrini S, Cignarelli A, et al. Insulin signaling in human visceral and subcutaneous adipose tissue in vivo. Diabetes. 2006;55(4):952-61 http:// www.ncbi.nlm.nih.gov/pubmed/16567516. Accessed 23 Dec 2018.

27. National Task Force on the Prevention and Treatment of Obesity. Overweight, obesity, and health risk. Arch Intern Med. 2000;160(7):898-904 http://www.ncbi.nlm.nih.gov/pubmed/10761953. Accessed 23 Dec 2018.

28. Geer EB, Shen W. Gender differences in insulin resistance, body composition, and energy balance. Gend Med. 2009;6:60-75. https://doi.org/ 10.1016/j.genm.2009.02.002.

29. Karelis AD, St-Pierre DH, Conus F, Rabasa-Lhoret R, PoehIman ET. Metabolic and body composition factors in subgroups of obesity: what do we know? J Clin Endocrinol Metab. 2004;89(6):2569-75. https://doi.org/10.1210/jc.2004-0165.

30. Sattar N, Gill JM. Type 2 diabetes as a disease of ectopic fat? BMC Med. 2014;12(1):123. https://doi.org/10.1186/s12916-014-0123-4.

31. Power ML, Schulkin J. Sex differences in fat storage, fat metabolism, and the health risks from obesity: possible evolutionary origins. Br J Nutr. 2008:99(5): 931-40. https://doi.org/10.1017/\$0007114507853347. 
32. Kvist $H$, Chowdhury B, Grangård U, Tylén U, Sjöström L. Total and visceral adipose-tissue volumes derived from measurements with computed tomography in adult men and women: predictive equations. Am J Clin Nutr. 1988:48(6):1351-61. https://doi.org/10.1093/ajcn/48.6.1351.

33. Lemieux S, Prud'homme D, Bouchard C, Tremblay A, Després JP. Sex differences in the relation of visceral adipose tissue accumulation to total body fatness. Am J Clin Nutr. 1993;58(4):463-7. https://doi.org/10.1093/ajcn/58.4.463.

34. Peters SAE, Bots SH, Woodward M. Sex differences in the association between measures of general and central adiposity and the risk of myocardial infarction: results from the UK Biobank. J Am Heart Assoc. 2018; 7(5). https://doi.org/10.1161/JAHA.117.008507.

35. Regensteiner JG, Golden S, Huebschmann AG, et al. Sex differences in the cardiovascular consequences of diabetes mellitus: a scientific statement from the American Heart Association. Circulation. 2015;132(25):2424-47. https://doi.org/10.1161/CIR.0000000000000343.

36. de Mutsert R, Gast K, Widya R, et al. Associations of abdominal subcutaneous and visceral fat with insulin resistance and secretion differ between men and women: the Netherlands Epidemiology of Obesity Study. Metab Syndr Relat Disord. 2018;16(1):54-63. https://doi.org/10.1089/met. 2017.0128.

37. Faulkner JL, Kennard S, Huby A-C, et al. Progesterone predisposes females to obesity-associated leptin-mediated endothelial dysfunction via upregulating endothelial MR (mineralocorticoid receptor) expression. Hypertens (Dallas). 2019;74(3):678-86. https://doi.org/10.1161/HYPERTENSIONAHA.119.12802.

38. Packer M. Leptin-aldosterone-neprilysin axis: identification of its distinctive role in the pathogenesis of the three phenotypes of heart failure in people with obesity. Circulation. 2018;137(15):1614-31. https://doi.org/10.1161/ CIRCULATIONAHA.117.032474.

39. Donahue RP, Rejman K, Rafalson LB, Dmochowski J, Stranges S, Trevisan M. Sex differences in endothelial function markers before conversion to pre-diabetes: does the clock start ticking earlier among women? The Western New York study. Diabetes Care. 2007;30(2):354-9. https://doi.org/10.2337/dc06-1772.

40. Haffner SM, Miettinen H, Stern MP. Relatively more atherogenic coronary heart disease risk factors in prediabetic women than in prediabetic men. Diabetologia. 1997;40(6):711-7. https://doi.org/10.1007/s001250050738.

41. Nakhjavani M, Morteza A, Meysamie A, et al. Serum heat shock protein 70 and oxidized LDL in patients with type 2 diabetes: does sex matter? Cell Stress Chaperones. 2011;16(2):195-201. https://doi.org/10.1007/s12192-010-0232-8.

42. Kautzky-Willer A, Harreiter J, Pacini G. Sex and gender differences in risk, pathophysiology and complications of type 2 diabetes mellitus. Endocr Rev. 2016;37(3):278-316. https://doi.org/10.1210/er.2015-1137.

43. de Ritter R, Sep SJS, van der Kallen CJH, Schram MT, Koster A, Kroon AA, et al. Adverse differences in cardiometabolic risk factor levels between individuals with pre-diabetes and normal glucose metabolism are more pronounced in women than in men: the Maastricht Study. BMJ Open Diabetes Res Care. 2019;7(1):e000787.

44. National Diabetes Audit - 2012-2013: Report 1, Care Processes and Treatment Targets - NHS Digital. https://digital.nhs.uk/data-and-information/publications/ statistical/national-diabetes-audit/national-diabetes-audit-2012-2013-report-1care-processes-and-treatment-targets. Accessed 26 June 2018.

45. Clinical Guidelines Task Force. Global Guideline fot Type 2 Diabetes. https:// www.idf.org/e-library/guidelines/79-global-guideline-for-type-2-diabetes. Published 2012. Accessed 2 Dec 2018.

46. Hyun KK, Redfern J, Patel A, et al. Gender inequalities in cardiovascular risk factor assessment and management in primary healthcare. Heart. 2017; 103(7):492-8. https://doi.org/10.1136/heartjnl-2016-310216.

47. Zhao M, Vaartjes I, Graham I, et al. Sex differences in risk factor management of coronary heart disease across three regions. Heart. 2017; 103(20):1587-94. https://doi.org/10.1136/heartjnl-2017-311429.

48. Eapen ZJ, Liang L, Shubrook JH, et al. Current quality of cardiovascular prevention for million hearts: an analysis of 147,038 outpatients from the Guideline Advantage. Am Heart J. 2014;168(3):398-404. https://doi.org/10. 1016/J.AHJ.2014.06.007.

49. Ferrara A, Mangione CM, Kim C, et al. Sex disparities in control and treatment of modifiable cardiovascular disease risk factors among patients with diabetes: Translating Research Into Action for Diabetes (TRIAD) Study. Diabetes Care. 2008;31(1):69-74. https://doi.org/10.2337/dc07-1244.

50. Franch-Nadal J, Mata-Cases M, Vinagre I, et al. Differences in the cardiometabolic control in type 2 diabetes according to gender and the presence of cardiovascular disease: results from the eControl study. Int J Endocrinol. 2014;2014:131709. https://doi.org/10.1155/2014/131709.
51. Gouni-Berthold I, Berthold HK, Mantzoros CS, Böhm M, Krone W. Sex disparities in the treatment and control of cardiovascular risk factors in type 2 diabetes. Diabetes Care. 2008;31(7):1389-91. https://doi.org/10.2337/dc08-0194.

52. Rossi MC, Cristofaro MR, Gentile $\mathrm{S}$, et al. Sex disparities in the quality of diabetes care: biological and cultural factors may play a different role for different outcomes: a cross-sectional observational study from the AMD Annals initiative. Diabetes Care. 2013;36(10):3162-8. https://doi.org/10.2337/dc13-0184.

53. Yu MK, Lyles CR, Bent-Shaw LA, Young BA. Sex disparities in diabetes process of care measures and self-care in high-risk patients. J Diabetes Res. 2013;2013:575814. https://doi.org/10.1155/2013/575814.

54. Tseng C-L, Sambamoorthi U, Rajan M, et al. Are there gender differences in diabetes care among elderly Medicare enrolled veterans? J Gen Intern Med. 2006;21(Suppl 3):S47-53. https://doi.org/10.1111/j.1525-1497.2006.00374.x.

55. Bird CE, Fremont AM, Bierman AS, et al. Does quality of care for cardiovascular disease and diabetes differ by gender for enrollees in managed care plans? Women's Heal Issues. 2007;17(3):131-8. https://doi.org/10.1016/J.WHI.2007.03.001.

56. Bird CE, Manocchia M, Tomblin B, et al. Mapping the gaps: gender differences in preventive cardiovascular care among managed care members in four metropolitan areas. Womens Health Issues. 2018;28(5):44655. https://doi.org/10.1016/j.whi.2018.04.008.

57. Billimek J, Malik S, Sorkin DH, et al. Understanding disparities in lipid management among patients with type 2 diabetes: gender differences in medication nonadherence after treatment intensification. Womens Health Issues. 2015;25(1):6-12. https://doi.org/10.1016/j.whi.2014.09.004.

58. Chou AF, Brown AF, Jensen RE, Shih S, Pawlson G, Scholle SH. Gender and racial disparities in the management of diabetes mellitus among Medicare patients. Women's Heal Issues. 2007;17(3):150-61. https://doi.org/10.1016/j. whi.2007.03.003.

59. Guthrie B, Emslie-Smith A, Morris AD. Which people with type 2 diabetes achieve good control of intermediate outcomes? Population database study in a UK region. Diabet Med. 2009;26(12):1269-76. https://doi.org/10.1111/j. 1464-5491.2009.02837.x.

60. Strom Williams JL, Lynch CP, Winchester R, Thomas L, Keith B, Egede LE. Gender differences in composite control of cardiovascular risk factors among patients with type 2 diabetes. Diabetes Technol Ther. 2014;16(7): 421-7. https://doi.org/10.1089/dia.2013.0329.

61. McGovern MP, Williams DJ, Hannaford PC, et al. Introduction of a new incentive and target-based contract for family physicians in the UK: good for older patients with diabetes but less good for women? Diabet Med. 2008;25(9):1083-9. https://doi.org/10.1111/j.1464-5491.2008.02544.x.

62. Williams JS, Bishu KG, St Germain A, Egede LE. Trends in sex differences in the receipt of quality of care indicators among adults with diabetes: United States 2002-2011. BMC Endocr Disord. 2017;17(1):31. https://doi.org/10.1186/ s12902-017-0183-5.

63. de Jong $M$, Vos $R C$, de Ritter $R$, et al. Sex differences in cardiovascular risk management for people with diabetes in primary care: a cross-sectional study. BJGP Open. 2019:bjgpopen19X101645. https://doi.org/10.3399/ bjgpopen19X101645.

64. Sabaté E, World Health Organization. Adherence to long-term therapies : evidence for action. World Health Organization; 2003. http://apps.who.int/ medicinedocs/en/d/Js4883e/. Accessed 11 Dec 2018.

65. Jackevicius CA, Li P, Tu JV. Prevalence, predictors, and outcomes of primary nonadherence after acute myocardial infarction. Circulation. 2008;117(8): 1028-36. https://doi.org/10.1161/CIRCULATIONAHA.107.706820.

66. Jackevicius CA, Mamdani M, Tu JV. Adherence with statin therapy in elderly patients with and without acute coronary syndromes. JAMA. 288(4):462-7 http://www.ncbi.nlm.nih.gov/pubmed/12132976. Accessed 11 June 2018.

67. Vrijens B, De Geest S, Hughes DA, et al. A new taxonomy for describing and defining adherence to medications. Br J Clin Pharmacol. 2012;73(5):691-705. https://doi.org/10.1111/j.1365-2125.2012.04167.x.

68. Kolandaivelu K, Leiden BB, O'Gara PT, Bhatt DL. Non-adherence to cardiovascular medications. Eur Heart J. 2014;35(46):3267-76. https://doi.org/ 10.1093/eurheartj/ehu364.

69. Ho PM, Rumsfeld JS, Masoudi FA, et al. Effect of medication nonadherence on hospitalization and mortality among patients with diabetes mellitus. Arch Intern Med. 2006;166(17):1836. https://doi.org/10.1001/archinte.166.17.1836.

70. Lewey J, Shrank WH, Bowry ADK, Kilabuk E, Brennan TA, Choudhry NK. Gender and racial disparities in adherence to statin therapy: a meta-analysis. Am Heart J. 2013;165(5):665-78, 678.e1. https://doi.org/10.1016/j.ahj.2013.02.011.

71. Cramer JA, Benedict A, Muszbek N, Keskinaslan A, Khan ZM. The significance of compliance and persistence in the treatment of diabetes, hypertension 
and dyslipidaemia: a review. Int J Clin Pract. 2008;62(1):76-87. https://doi. org/10.1111/j.1742-1241.2007.01630.x

72. Iglay K, Cartier SE, Rosen VM, et al. Meta-analysis of studies examining medication adherence, persistence, and discontinuation of oral antihyperglycemic agents in type 2 diabetes. Curr Med Res Opin. 2015;31(7): 1283-96. https://doi.org/10.1185/03007995.2015.1053048.

73. Odegard PS, Capoccia K. Medication taking and diabetes: a systematic review of the literature. Diabetes Educ. 2007;33(6):1014-29. https://doi.org/ $10.1177 / 0145721707308407$.

74. Wong MCS, Kong APS, So W-Y, Jiang JY, Chan JCN, Griffiths SM. Adherence to oral hypoglycemic agents in 26,782 Chinese patients: a cohort study. J Clin Pharmacol. 2011;51(10):1474-82. https://doi.org/10.1177/ 0091270010382911.

75. Curkendall SM, Thomas N, Bell KF, Juneau PL, Weiss AJ. Predictors of medication adherence in patients with type 2 diabetes mellitus. Curr Med Res Opin. 2013;29(10):1275-86. https://doi.org/10.1185/03007995.2013.821056.

76. Hertz RP, Unger AN, Lustik MB. Adherence with pharmacotherapy for type 2 diabetes: a retrospective cohort study of adults with employer-sponsored health insurance. Clin Ther. 2005;27(7):1064-73. https://doi.org/10.1016/j. clinthera.2005.07.009

77. Tiv M, Viel J-F, Mauny F, et al. Medication adherence in type 2 diabetes: the ENTRED Study 2007, a French population-based study. Malaga G, ed. PLoS One. 2012;7(3):e32412. doi:https://doi.org/10.1371/journal.pone.0032412

78. Donnan PT, MacDonald TM, Morris AD. Adherence to prescribed oral hypoglycaemic medication in a population of patients with type 2 diabetes: a retrospective cohort study. Diabet Med. 2002;19(4):279-84. https://doi.org/ 10.1046/j.1464-5491.2002.00689.x.

79. Wong KW, Ho SY, Chao DVK. Quality of diabetes care in public primary care clinics in Hong Kong. Fam Pract. 2012;29(2):196-202. https://doi.org/10. 1093/fampra/cmr060.

80. Barker LC, Kurdyak P, Jacob B, Vigod SN. Quality of diabetes care for individuals with comorbid chronic psychotic illness: a sex-based analysis. J Women's Heal. 2018;27(3):290-6. https://doi.org/10.1089/jwh.2017.6490.

81. Baviera M, Santalucia P, Cortesi L, et al. Sex differences in cardiovascular outcomes, pharmacological treatments and indicators of care in patients with newly diagnosed diabetes: analyses on administrative database. Eur $J$ Intern Med. 2014:25(3):270-5. https://doi.org/10.1016/..ejim.2014.01.022.

82. Gnavi R, Picariello R, la Karaghiosoff L, Costa G, Giorda C. Determinants of quality in diabetes care process: the population-based Torino Study. Diabetes Care. 2009;32(11):1986-92. https://doi.org/10.2337/dc09-0647.

83. Correa-de-Araujo R, McDermott K, Moy E. Gender differences across racial and ethnic groups in the quality of care for diabetes. Women's Heal Issues. 2006;16(2):56-65. https://doi.org/10.1016/J.WHI.2005.08.003.

84. Nau DP, Mallya U. Sex disparity in the management of dyslipidemia among patients with type 2 diabetes mellitus in a managed care organization. Am J Manag Care. 2005;11(2):69-73 http://www.ncbi.nlm.nih.gov/pubmed/15 726854. Accessed 7 May 2019.

85. Willis TA, West $R$, Rushforth $B$, et al. Variations in achievement of evidencebased, high-impact quality indicators in general practice: an observational study. Asnani MR, ed PLoS One. 2017;12(7):e0177949. doi:https://doi.org/10. 1371/journal.pone.0177949

86. Choe S-A, Kim JY, Ro YS, Cho S-I. Women are less likely than men to achieve optimal glycemic control after 1 year of treatment: a multi-level analysis of a Korean primary care cohort. PLoS One. 2018;13(5):e0196719. https://doi.org/10.1371/journal.pone.0196719.

87. Wexler DJ, Grant RW, Meigs JB, Nathan DM, Cagliero E. Sex disparities in treatment of cardiac risk factors in patients with type 2 diabetes. Diabetes Care. 2005;28(3):514-20. https://doi.org/10.2337/DIACARE.28.3.514.

\section{Publisher's Note}

Springer Nature remains neutral with regard to jurisdictional claims in published maps and institutional affiliations.

Ready to submit your research? Choose BMC and benefit from:

- fast, convenient online submission

- thorough peer review by experienced researchers in your field

- rapid publication on acceptance

- support for research data, including large and complex data types

- gold Open Access which fosters wider collaboration and increased citations

- maximum visibility for your research: over $100 \mathrm{M}$ website views per year

At BMC, research is always in progress.

Learn more biomedcentral.com/submissions 